\title{
Relation of serum leptin level to hypertensive retinopathy
}

\author{
Hoda Abd El-Baset Mohamed, Sawsan Abd El-Sabour Shalaby* and Amal \\ Abdel-Aleem Morsy**
}

General Medicine, *Ophthalmology and **Clinical Pathology Departments

\begin{abstract}
Leptin plays a promoting role in angiogenesis and the vascular endothelium express the long form of leptin receptor, therefore, the aim of the work was to assess the plasma level of leptin in hypertensive patients and to evaluate the relationship between its concentration and hypertension. and hypertensive retinopathy, also to assess its relation to body mass index.

This study was carried out on 50 patients with essential hypertension and 25 normal healthy, age and sex matched control subjects. Patients with essential hypertension were classified into 2 groups according to the presence or absence of retinopathy, 25 patients without hypertensive retinopathy (Group II a) and 25 patients with hypertensive retinopathy (Group II b).

The study showed significantly very higher serum leptin in group II and its subgroups ( II a and II b) compared to those of the control (Group I), despite no significant difference was detected between the three groups (group I , II a and II b) regarding age, sex and body mass index. Also no significant deference was detected between hypertensive group without retinopathy and hypertensive retinopathy group as regard mean blood pressure.

Positive correlation between serum leptin level and mean blood pressure among all groups was found. Also positive correlation between serum leptin level and body mass index (BMI) among all groups.
\end{abstract}

\section{Introduction}

The pathophysiological mechanism of hypertensive retinopathy is not fully established. The autoregulation of retinal circulation failed as the blood pressure increased beyond the critical limit . Also humoral components may be involved as well (Lowenthel and Zimlichmun, 1993)

Leptin is a hormone (167 amino acid protein) secreted primarily by adipocytes mainly in adipose tissue, gastric epithelium and placenta. It plays an important role in regulation of blood intake and energy expenditure (Korbonits et al 2001).It increases the vascular permeability through stimulation of short form receptors (Cao et al 2001). Leptin induces endothelial cells migration which is the key event in angiogenesis (Goetze et al 2002). Yamagishi et al (2004). attributed the development and progression of retinopathy to loss and dysfunction of pericytes.

\section{Aim of the study:}

Is to evaluate the plasma leptin level in relation to the grades of hypertensive retinopathy and also to assess its level in hypertensive patients and its relation to their body mass index.

\section{Subjects and methods}

This study was done on 50 patients with essential hypertension (24 males and 26 females) with mean age of $45.54 \pm 4.32$ years compared to 25 healthy normotensive subjects age, sex and body mass index matched as control group (12 males and 13 females). with mean age of $44.20 \pm 3.86$ years.

The included subjects were classified into two groups:

Group I: 25 healthy normotensive subjects as control 
Group II: 50 patients with essential hypertension, they were divided according to the presence or absence of retinopathy into two subgroups:

Group II a: 25 patients without hypertensive retinopathy

Group II b : 25 patients with hypertensive retinopathy.

Patients with diabetes mellitus, ischemic heart diseases heart failure, chronic renal or liver diseases and psychological disturba-nces were excluded from this study as these may affect plasma leptin level.

Full history and complete clinical examination were done for all patients and control with stress on age, sex, systolic , diastolic and mean blood pressure (MBP) which equals diastolic blood pressure $+1 / 3$ pulse pressure) and body mass index (weight in $\mathrm{Kg} /$ height 2 in meter), heart ,chest and abdominal examination.

Ophthalmological examinations were done and included:-

- visual acuity measure-ment

- Intraocular pressure measurements

- Fundus examination and fundus photography (coloured) and fundus fluorescein angiography.

- We use grading stated by Kanski (1999) of patients with hyperte-nsive retinopathy as follow:

Grade I: consists of mild generalized arteriolar attenuation, particularly of small branches, with broadening of the arteriolar light reflex and vein concealment.

Grade II: More sever generalized as well as focal arteriolar narrowing with deflection of veins at arteriovenous (A/V) crossings Fig (2).

Grade III: Copper wiring of arterioles, banking of veins distal to $\mathrm{A} / \mathrm{V}$ crossing and right- angled deflection of veins flame shaped haemorrhages and exudates either hard or cotton-wool

Grad 4 : Changes as grade 3 in addition to disc swelling and silver- wiring of arterioles NB : Only patients with grades 1 and 2 hypertensive retinopathy were included, as patients with advanced stages of retinopathy were not included because most had renal and cardiac complications that could influence the plasma leptin level.

\section{Laboratory investigations :}

- Fasting and 2 hours blood glucose levels

- Kidney function tests

- Liver functions

- Lipids profile

- ECG to exclude any heart problems.

- Determination of serum leptin in $\mathrm{ng} / \mathrm{ml}$ was done using diagnostic bio Canad Inc (dbc) No: 4260 cat by enzyme linked immunosorbent assay bits (ELIZA).

- NB: Statistical analysis was done by using mean, standard deviation (SD), minimum and maximum values and $\mathrm{P}$ value.

\section{Results}

This study was conducted on 50 patients with essential hypertension (group II) and 25 healthy normotensive age,sex and BMI matched subjects as control group (group I).

The main clinical symptoms was headache in 25 patients (50\%),3 patients (6\%) had epistaxis while 12 patients (24\%) had no symptoms and known to have hypertension while 10 patients (20\%) accidentally discovered to be hypertensive.

The age of patients (Group II) ranged from 38 to 55 years with a mean SD of $45.54 \pm 4.32$ years. Twenty four $(48 \%)$ were male and $26(52 \%)$ were female. The mean \pm SD of their body mass index (BMI) was $26.26 \pm 4.41$.

The hypertensive patients were divided into two groups according to the presence (IIb) or absence (IIa) of hypertensive retinopathy.

The mean \pm SD of mean blood pressure (MBP) were very highly significantly increased in hypertensive group (II) (126.13 7..81) than that of control group (I) (88.19 6.28) ( $\mathrm{P}$ 0.001) and no significant difference in mean \pm SD of MBP of group IIa versus group IIb were found (table 1).

The mean \pm SD of serum leptin level were very highly significantly increased in hypertensive group (II) $(29.74 \pm 22.46 \mathrm{ng} / \mathrm{dl})$ 
compared to the control group (I) $(7.06 \pm 4.87 \mathrm{ng} / \mathrm{dl})$ and in group IIb versus group I while highly significantly increased in group IIa $(22.62 \pm 19.85)$ versus group I $(7.06 \pm 4.87) \quad(\mathrm{p}<0.01) \quad$ and significant increase in group IIb $(36.86 \pm 23.03)$ versus group IIa (table 2).
As regard BMI, there was no significance difference of mean $\pm \mathrm{SD}$ of BMI of group IIa and IIb versus control and group IIa versus group IIb.

There was positive correlation between serum leptin level and also BMI (table 3) and MBP (table 4) in all groups I, IIa, IIb.

Table (1): Mean values of MBP among all studied groups .

\begin{tabular}{|l|c|c|c|}
\hline Group & Mean \pm SD of MBP & p. value & Significance \\
\hline I & $88.19 \pm 6.28$ & $<0.001$ & V. H. S. \\
II & $126.13 \pm 7.81$ & $<0.001$ & V. H. S. \\
I & $88.19 \pm 6.28$ & & \\
\hline I & $125.15 \pm 7.15$ & $<0.001$ & V. H. S. \\
IIb & $127.19 \pm 6.28$ & & \\
\hline IIa & $125.15 \pm 7.15$ & $>0.05$ & N. S. \\
IIb & $127.11 \pm 8.47$ & & \\
\hline
\end{tabular}

Table (2) Serum leptin among all studied groups

\begin{tabular}{|c|c|c|c|}
\hline Group & $\begin{array}{c}\text { Mean } \pm \text { SD of } \\
\text { serum leptin }\end{array}$ & p. value & Significance \\
\hline I & $\begin{array}{c}7.06 \pm 4.87 \\
29.74 \pm 22.46\end{array}$ & $<0.001$ & V. H. S. \\
\hline $\begin{array}{l}\text { I } \\
\text { IIa }\end{array}$ & $\begin{array}{c}7.06 \pm 4.87 \\
22.62 \pm 19.85\end{array}$ & $<0.01$ & H. S. \\
\hline $\begin{array}{l}\text { I } \\
\text { Iib } \\
\end{array}$ & $\begin{array}{c}7.06 \pm 4.87 \\
36.86 \pm 23.03 \\
\end{array}$ & $<0.001$ & V. H. S. \\
\hline $\begin{array}{l}\text { IIa } \\
\text { IIb }\end{array}$ & $\begin{array}{l}2.62 \pm 19.85 \\
36.86 \pm 23.03\end{array}$ & $<0.05$ & S. \\
\hline
\end{tabular}

Table (3) Correlation between serum leptin level and body mass index (BMI)among all groups

\begin{tabular}{|l|c|c|c|}
\hline BMI & R. value & P. value & significant \\
\hline Group II & 0.445 & $<0.05$ & $\mathrm{~S}$ \\
\hline Group I control & 0.481 & $<0.05$ & $\mathrm{~S}$ \\
\hline Group II a & 5.437 & $<0.05$ & $\mathrm{~S}$ \\
\hline Group II b & 0.470 & $<0.05$ & $\mathrm{~S}$ \\
\hline
\end{tabular}


Table (4) Correlation between serum leptin level and mean blood pressure (MBP) among all groups.

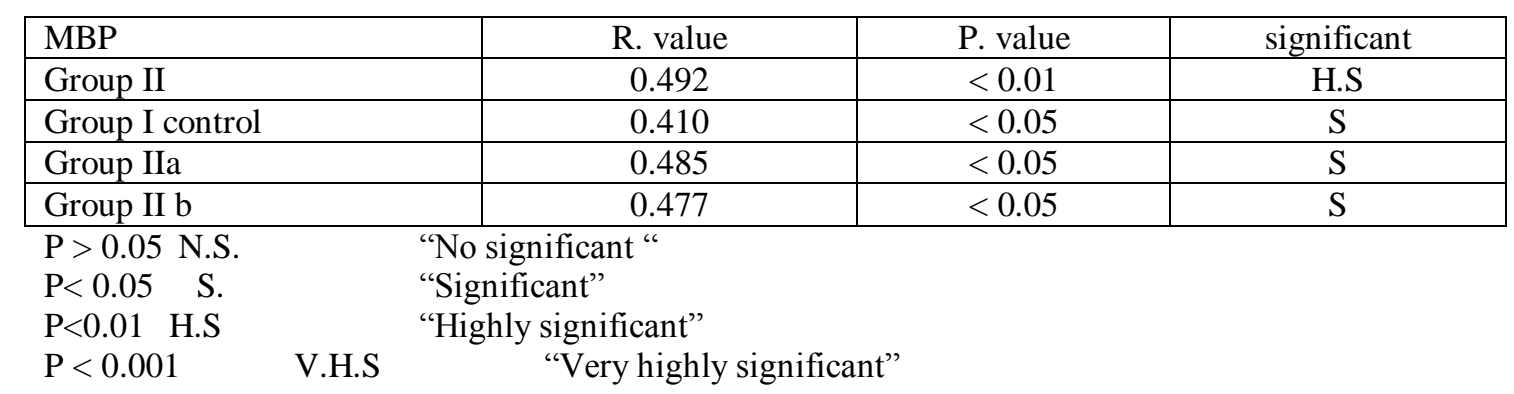

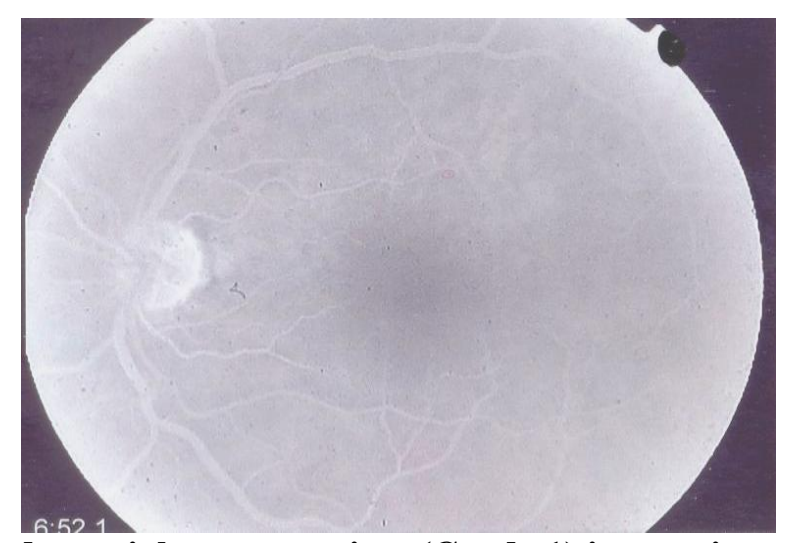

Fig (1) Generalized arteriolar attenuation (Grade 1) in arteriovenous phase (FFA).

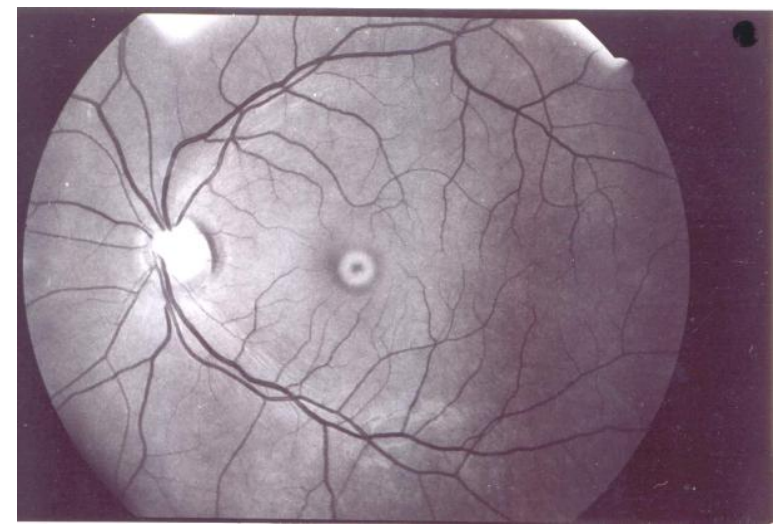

Fig (2) Sever generalized arteriolar attenuation with arteriovenous crossing (Grade 2) with red free photography .

\section{Discussion}

Epidemiological studies have clearly demonstrated that elevated blood pressure is a major cause of premature vascular disease leading to cerebro vascular events, ischaemic heart disease and peripheral vascular disease (Kumar\& Clark 2002).

Hypertensive blood vessel damage in the eye is linked with similar changes in brain and has been shown to be associated with higher risk of stroke and death (Kumar and Clark, 2002).

The pathogenesis of essential hypertension remain unclear but increase in body weight most of time is associated with hypertension also there are several reports indicating that leptin may has a role in 
hypertension (Canatan et al., 2004).

Leptin plays an important role in regulation of food intake, energy expenditure and body weight regulation (Havel, 2000). It was expressed in adipose tissue, gastric epithelium, skeletal muscle (Ahima and Flier, 2000) and brain (Korbonits et al., 2001). Plasma leptin level correlated with body fat content, It is elevated in obesity and decreased in anorexia nervosa. Moreover it has been shown that in addition to its effect on food intake and energy expenditure, leptin affects autonomic, cardiovascular, renal and endocrinal functions (Korbonits et al., 2001).

It has also recently been shown that leptin plays a promoting role in angiogenesis and that vascular endothelium expresses the long form of leptin so leptin might contributes to end organ damage in hypertension (Uckaya et ai, 2000). In the present study we evaluated the relationship between plasma leptin concentration and hypertensive retinopathy.

Fifty patients with essential hypertension and 25 healthy normotensive control subjects matched for age, sex and body mass index were enrolled in the study. For assessment of retinopathy according to Kanski (1999) grading direct and indirect ophthalmoscope and fundus fluroescein angiography (FFA) were performed on hypertensive group. Twenty five patients had hypertensive retinopathy and 25 patients had normal fundus. Our work demonstrated significantly very higher serum leptin in patients with hypertension (Leptin 29.74 \pm 22.46 ) compared to those of control group $(7.06 \pm 4.87)$, $(\mathrm{P}$ value $<0.001)$ despite no significant difference was detected between the twogroups regarding body mass index and mean blood pressure ( $\mathrm{p}<05)$. Our results are in accordance with Hirose et al., (1998) who reported positive correlation between leptin and mean blood pressure also after adjustment for age and body mass index. Stefan et al., (1998) and Suter et al., (1998) showed that subjects with stage I hypertension had significantly higher plasma leptin level than normotensive subject. also showed that serum leptin concentration correlated with systolic and diastolic blood pressure. While
Kennedy et al., (1998) demonstrated a relationship between elevated systolic blood pressure and diastolic blood pressure and plasma leptin level in hypertensive men only. Markis et al., (1998) demonstrated higher leptin and insulin level in healthy offspring of patients with hypertension compared to healthy offspring of normotensive patients which may reflect genetic bases of hypertension. Barba et al., (2003) and Eikelis et al., (2004) reported that plasma leptin level correlated with mean blood pressure independent of body mass and body fat content These results is supported by the action of leptin as it increases sympathetic activity (Anisley et al., 2003) and increases plasma renin, aldosteron, angiotensinogen release (Suter et al., 1998) also leptin induces the release of IL-6 from adipose tissues which in turn increases the $\mathrm{C}$ reactive protein from liver leading to endothelial dysfunction and decrease nitric oxide release (Undurti, 2002). The natriuretic effect of leptin is blunted in obesity and hypertension by increase renal sympathetic activity and by up regulating Na- K ATPases causing sodium reabsorption (Bettowski et al., 2004)

In contrast neither Lonnqvist et al., (1997) Nor Mohammed Ali et al., (1997) found correlation between blood pressure and plasma leptin level. Narkiewicz et al., (1999) found that plasma leptin is significantly correlated with heart rate and diastolic blood pressure but not with 24 hours ambulatory systolic blood pressure in 60 men with essential hypertension. While Kokot et al., 1999 found no difference in plasma leptin level between hypertensive patients and control in a small sample of hypertensive patients. Rutkowski et al., (1999) found that ob gene is not a major contributor to phenotype of essential hypertension in African American.

The reason for divergent finding of these results are not obvious but may be due to factors such as race, selection criteria, limited numbers of patients, statistical methods, insulin resistance and difference antihypertensive treatment (Steinvinkel, 2000).

Also our work demonstrated significantly higher serum leptin level in patients 
with hypertensive retinopathy compared to those of hypertensive patients without retinopathy $(\mathrm{P}<0.05)$ and significantly very higher serum leptin in patients with hypertensive retinopathy compared to those of control group $(\mathrm{P}<0.001)$, despite no significant difference was detected between three groups regarding body mass index $(\mathrm{P}<0.05)$. Also no significant difference was detected between hypertensive group and hypertensive retinopathy group as regard mean blood pressure $(\mathrm{p}<0.05)$. This data agree with a study performed by Uckaya et al., (2000) who stated that leptin was higher in patients with hypertensive retinopathy than patients with hypertension and control after correction for body mass index.The role of leptin in hypertensive retinopathy is supported byBouloumie et al., (1998) who reported that leptin promotesangiogenesis in human unbilical venous cell and aortic endothelial cells. Sierra Honigmann et al., (1998) showed that leptin stimulates in vivo angiogenesis in the cornea also Yamagishi et al., (2004) reported that leptin stimulates vascular endothelial growth factor induction as well as pigment epithelium derived factor suppression both lead to parricides loss and dysfunction which is an early phase of retinopathy. Tanaka et al., (1999) reported that leptin induced endothelial cell migration which is a key event in angiogenesis also Cao et al., (2001) reported that leptin increases the vascular permeability. Konstantinides et al., (2001) reported that leptinpotentiates aggregation of platelet and formation of thrombi.

Singhal et al., (2002) reported that High leptin level is predictive of poor vascular compliance which accompanied the atherosclerosis.

Our result demonstrated that there is significantly positive colt elation between serum leptin level and body mass index within the control group and Hypertensive groups, the same results was obtained by Leyva et al (1998); Yoshinari et al (1998) and Ruhi and Everhart (2001).

\section{Conclusion}

The same work may be done to study the possible improvement of retinopathy with restrict control of hypertension and obesity.

Researches must be continued for leptin antagonist to stop the end organ damage secondary to hyperleptinaemia in obese individual.

\section{Refference}

1. Ahima RS and Flier JS., (2000): Leptin. Ann. Revi. Physiol 62; 413-37.

2. Anisley J. March, Marco AP, Killinger S et al., (2003): Cardiovascular responses evoked by leptin acting on neuron in ventromedial and dorsomedial Hypothalamus,Ann Revi Physiol 69; 512-54.

3. Barba G, Russo O, Siani A et al., (2003): Plasma leptin and blood pressure in men: Graded association independent of body mass and fat pattern. Obes. Res.; 11 (1): 160-166.

4. Bettowski J, Wisniewske JA, Borkoutska E et al., (2004): Upregulation of renal $\mathrm{Na}-$ $\mathrm{K}$ A Taps the possible novel mechanism of le $\mathrm{pt}$ in induced hypertension. Hypertension.32; 526-46.

5. Bouloumie A, Drexler HCA, Lafontan M, Busse R., (1998): Leptin the product of ob gene promotes angiogenesis Circul. Res. ; 83: 1059-1066.

6. Canatan H, Bakan I, Akbulut M Halifeoglu I, et al (2004): Relationship among levels of leptin and zinc,copper, and zinc/copper ratio in plasma of patients with essential hypertension and healthy normotensive subjects. Biol Trace Elem Res. 100(2): 117-123.

7. Cao R, Brakenhielm B, Wahlestedt C, Thyberg $\mathbf{J}$ et al., (2001): Leptin induces vascular permeability and synergistically stimulates angiogenesis with FGF-2 and VEGF. Proc, Natl. Acad. Sci. USA.; 98 (11): 6390-6395.

8. Carla T., (2003): Hypertensive retinopathy. Myron yanoff and Duker, 13 ed. Ophthalmology, an textbook, Moshy. C8-P16.

9. Eikelis N, Schlaich M, Aggarwal A, Kaye D, Esler M., (2004): Interactions between leptin and the human sympathetic nervous system. Hypertension; 41(5): 1072-9.

10. Goetze S, Bungenstock A, Czupalla C, Eilers F et al., (2002): Leptin induces endothelial cell migration. Hypertension; 40(5): 748-54.

11. Havel P J., (2000): Role- of adipose tissue in body-weight regulation: mechanisms 
reguLating leptin production and energy balance. Proc Nutr Soc; 59(3):359-71.

12. Hirose H, Saito I, Tsujioka M, Mori M et al., (1998): The obese gene product; leptin : Possible role in obesity related hypertension in adolescent.J. Hypertens.;16:2007-12.

13. Kanski JJ (1999): Grading of hypertensive retinopathy in retinal vascular diseases.Clinical ophthalmology a syste-mic approach $4^{\text {th }}$ ed. Butterworth and heim-ann (eds).Ch12P:497 Oxford, Auckland Boston, Johannesburg, Melbourne and New Delhi.

14. Kennedy A, Gettys TW, Watson P et al.,(1998): The metabolic significance of leptin in humans: gender-based differences in relationship to adiposity, insulin sensitivity, and energy metabolism. J Clin Endocrinol Metab.; 82: 1293-1300.

15. Kokot, Wiecek A, Adamczak M, Ulman I et al., (1999): Pathophysiologial role of leptin in patients with chronic renal failure, in kidney transplant patients, in patients with essential hypertension, and in pregnant women with perrclampsia. Artif Organs; 23(1): 70-4.

16. Konstantinides S, Schafer K, Koschnick S, Loskutoff DJ., (2001): Leptin- dependent platelet aggregation and arterial thrombosis suggests a mechanism for atherothrombotic disease in obesity. J Clin Invest; 108(10): 1533-40.

17. Korbonits M, Chinis MM, Gueorguiev M, Norman D et al., (2001): The release of leptin and its effect on hormone release from human pituirary adenomas. Clin Endocrinol. (Oxf). 54(6): 781-9.

18. Kumar and Clark., (2002): Cardiovascular disease systemic hypertension clinical medicine $4^{\text {th }}$ edition P: $729-740$.

19. Leyva F, Godsland IF, Ghate; M, Proudler AG et al.,(1998): Hyperleptinemia as a component of metabolic syndrom of cardiovascular risk. Arterioscler. Thromb. Vascu. Biol.; 6:926-33.

20. Lonnqvist F, Wennund A, Arner P., (1997): Relationship between cir,culating leptin and peripheral fat distribution in obese subjects. 1nt J Obes Relat Metab Disord. 21:255-260.

21. Lowenthal MN, Zimlichman R., (1993): Resolution of hypertensive retinopathy despite persistent high diastolic pressure. South Med J. 86: 190-193.

22. Makris TK, Stavroulakis GA, Krespi PG et al., (1998): Elevated fibroblast growth factor in endothelial cells during for the ob gene product leptin in essential hypertension. Am J Heart;138: 922-925.
23. Narkiewicz I, Somers VI( Mos L, Kato M, Accurso $V$ et al., (1999): An independent relationship between plasma leptin and heart rate in untreated patients with essential hypertension. J Hypertension 17:245-249

24. Ruhi CE and Everhart JE., (2001): Leptin concentration in united state. Relation with demographic and anthropometric Measure Am J clin. Nut. 74: 295-301.

25. Rutkowski MP, Klanke CA, Su YR, Reif $M$ et al.,(1999): Genetic markers at the leptin (OB) locus are not significantly linked hypertension in African Americans. Hypertension; 31: 12301236

26. Sierra-Honigmann MR, Nath AK, Murakami C et al., (1998): Biological action of leptin as an angiogenic factor. Science; 281: 1683-6.

27. Singhal A, Farooqi, IS, Cole T J et al., (2002): Influence of leptin on arterial distinsibility; a novel, link between obesity and cardiovascular disease circul 106: 1919-1934.

28. Stefan RB, David JT, Murakami C et al., .(1998): Leptin and rennin angiotensin-aldosteron system. J Hypertension 32;376-377.

29. Steinvinkel P., (2000): Leptin and blood pressure-is there a link Nephrol Dial Tranplant.; 15:1115-1117.

30. Suter PM, Locher R, Hasler E, Vet/er w., (1998): Is there a role for the ob gene product leptin in essential hypertension. Am J. Hypertension; 11: 305-131

31. Tanaka K, Ahe M, Sato., (1999): Roles of extracellular signal regulated kinase. $1 / 2$ in the signal transduction of basic fibroblast growth factor in endothelial cells during angiogenesis Jpn J Cancer Res.; 90: 647-654.

32. Uckaya G, Ozata M, Sonmez A et al., (2000): Is leptin associated with hypertensive retinopathy $\mathrm{J}$ clin endocrinol. Metab 85; 683-687.

33. Undurti N., (2002): Is metabolic syndrome $\mathrm{X}$ an iriflammatory /condition Exp. Biol. Med. 227:989-997.

34. Yamagishi S, Inagaki Y, Amano S, Okamoto T, Takeuchi M et al., (2004): Up-regulation of vascular endothelial growth factor and down-regulation of pigment epithelium-derived factor messenger ribonucleic acid levels in leptin-exposed cultured retinal pericytes. Int. J. Tissue Reac. 24: 137-42.

35. Yoshinari M, Wakisaka M, Fujishima M., (1998): Serum leptin level in smoker with type II diabetes. Diabetes care. 21: 516-7. 


\title{
علاقة مستوي اللبتن بالبلازما واعتلال الثبكية الناتج عن فرط ضغط الدم الثرياني
}

\author{
هدى عبد الباسط محمد حس ,* سوسن عبد الصبورشلبى, **|مل عبد العليم

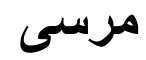 \\ اقسام الباطنة العامة,* طب وجر احة العيون ** الباثولوجيا الاكلينيكية.
}

يعتبر اللبتن نتاج جين السمنة ويفرز اساسا من الخلايا الدهنية ونسبته في الدمام

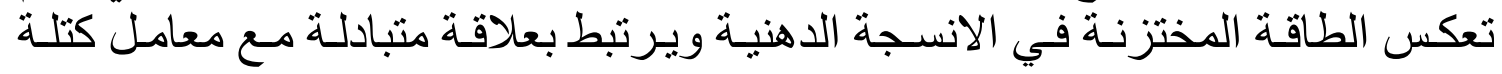

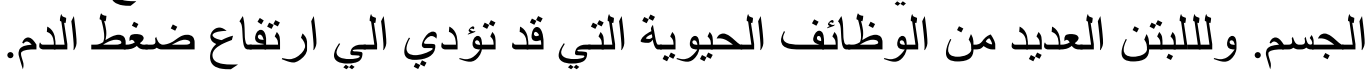

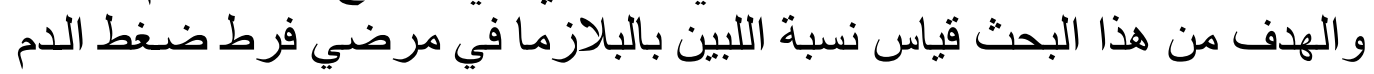

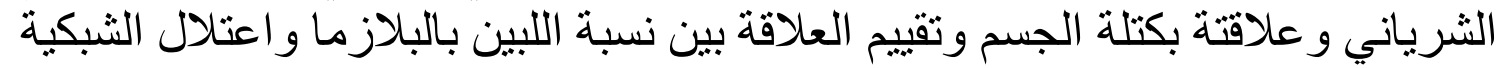

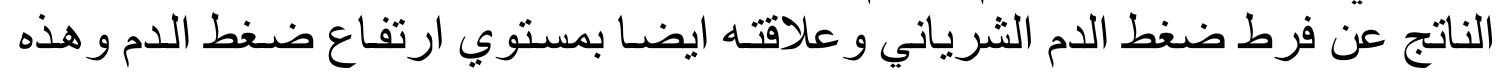

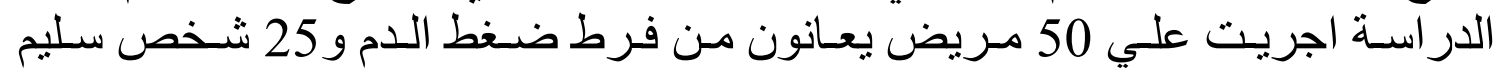

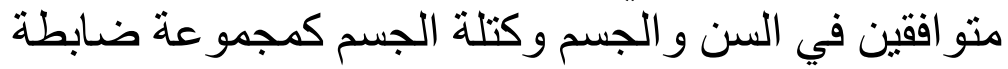
وتم تقسيمهم كالاتي المجمو عة الاولي تشمل 25 شخص سليم سليم كمجمو عة ضابطة

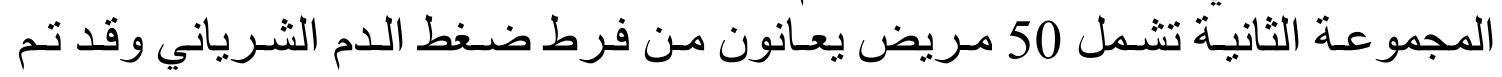
تقسيمهم الي مجمو عتيتن جزئيتين

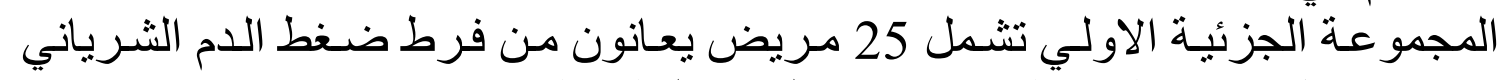

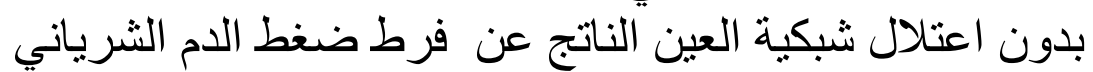

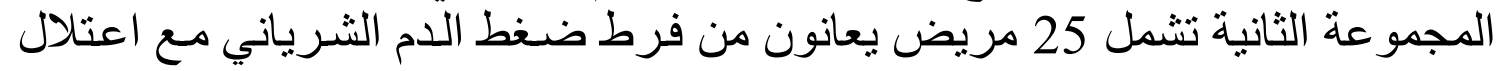

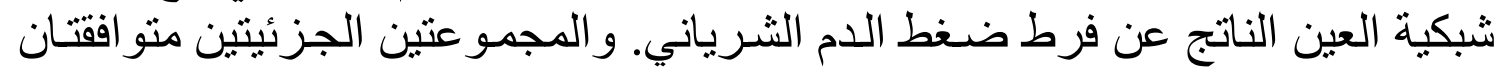

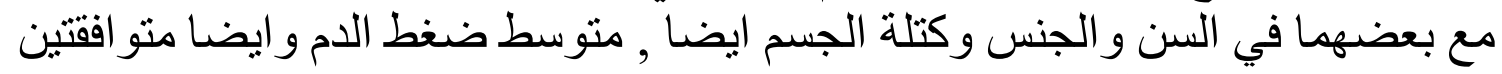
مع المجمو عة الضابطة في السن و الجسم وكتلة الجسم.

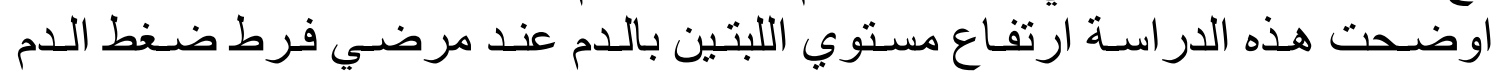

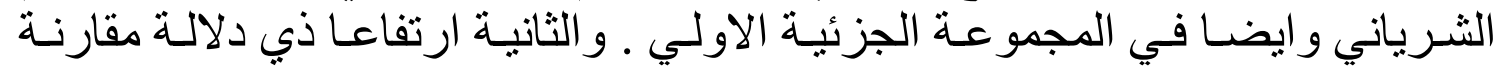

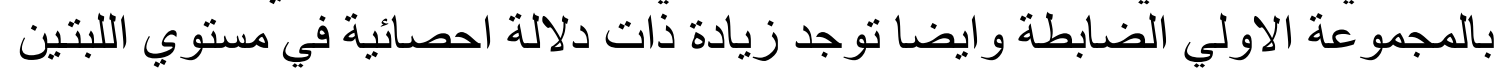

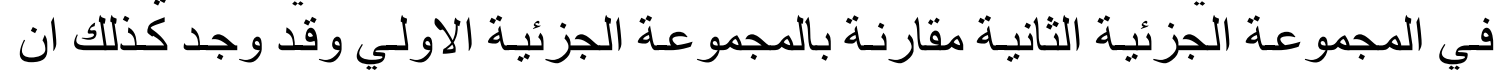

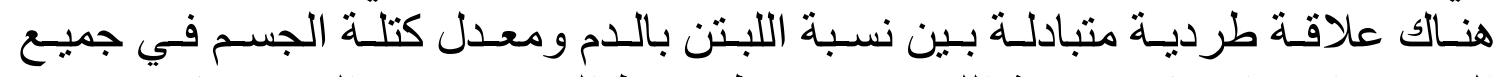

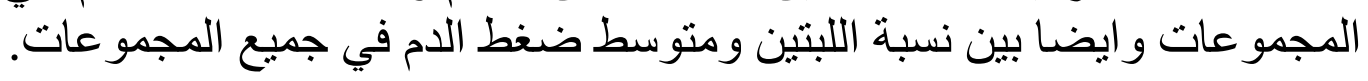

